\title{
Charge-transfer Interactions between Sulfur Dioxide and Group 8 Half-sandwich Complexes
}

\author{
Chris Hall, Jeremy L. Harris, ${ }^{a}$ Adelle Killey, Tania P. Maddox, ${ }^{a}$ Stephen Palmer, ${ }^{a}$ \\ Robin N. Perutz,,$^{* a}$ A. Denise Rooney, ${ }^{a}$ Simon E. J. Goff, ${ }^{b}$ Sergei G. Kazarian ${ }^{b}$ and \\ Martyn Poliakoff ${ }^{b}$ \\ ${ }^{a}$ Department of Chemistry, University of York, York YO1 5DD, UK \\ ${ }^{b}$ Department of Chemistry, University of Nottingham, Nottingham NG7 2RD, UK
}

\begin{abstract}
Mulliken-type charge-transfer complexes have been formed between basic half-sandwich compounds and $\mathrm{SO}_{2}$ when $\left[M\left(\eta^{5}-C_{5} R_{5}\right)(C O)_{2}\right]\left(M=R h\right.$ or Ir; $R_{5}=M e_{5}, H_{5}$ or $\left.H_{4} C F_{3}\right)$. $\left[\operatorname{Ir}\left(\eta^{5}-C_{5} H_{5}\right)(C O)\left(C_{2} H_{4}\right)\right]$, and $\left[M\left(\eta^{5}-C_{5} H_{5}\right)\left(C_{2} H_{4}\right)_{2}\right]\left(M=C o, R h\right.$ or Ir) are isolated in $S_{2}$-doped argon matrices at $20 \mathrm{~K}$; the $v(\mathrm{CO})$ bands of the complexes are shifted to high frequency of those of the precursor molecules and prominent charge-transfer bands are observed; the same species have been detected when the compounds $\left[M\left(\eta^{5}-C_{5} M_{5}\right)(C O)_{2}\right](M=R h$ or Ir) are embedded in polyethylene discs and treated with $\mathrm{SO}_{2}$ at $213-298 \mathrm{~K}$; the enthalpy of complexation of $\left[\operatorname{lr}\left(\eta^{5}-\mathrm{C}_{5} \mathrm{Me}_{5}\right)(\mathrm{CO})_{2}\right]$ with $\mathrm{SO}_{2}$ is $-13 \pm 3$ $\mathrm{kJ} \mathrm{mol}^{-1}$.
\end{abstract}

Kubas $^{1}$ has argued that sulfur dioxide is the most versatile ligand or complexing agent known, and has shown how its oxygen transfer reactions at organometallic centres may be used for catalytic formation of elemental sulfur. In one of the earliest examples of complexation, Cramer ${ }^{2}$ showed that $\mathrm{SO}_{2}$ reacts with $\left[\mathrm{Rh}\left(\eta^{5}-\mathrm{C}_{5} \mathrm{H}_{5}\right)\left(\mathrm{C}_{2} \mathrm{H}_{4}\right)_{2}\right]$ to form $\left[\mathrm{Rh}\left(\eta^{5}-\mathrm{C}_{5} \mathrm{H}_{5}\right)\left(\mathrm{C}_{2} \mathrm{H}_{4}\right)-\right.$ $\left.\left(\mathrm{SO}_{2}-\mathrm{S}\right)\right]$ at $-80^{\circ} \mathrm{C}$. This substitution reaction was postulated to occur at exceptionally low temperature because the $\mathrm{SO}_{2}$ could act initially as a Lewis acid towards the rhodium complex. No further examples of the Group 8 half-sandwich complexes have been discovered, probably because they are hard to control. We now report that $\mathrm{SO}_{2}$ forms charge-transfer (c.t.) complexes, without substitution, with a variety of Group 8 halfsandwich compounds, and that such complexes can be characterised in low-temperature matrices and in polyethylene discs.

The IR spectrum of $\left[\operatorname{Ir}\left(\eta^{5}-\mathrm{C}_{5} \mathrm{Me}_{5}\right)(\mathrm{CO})_{2}\right]$ isolated in a pure argon matrix at $20 \mathrm{~K}$ shows two $v(\mathrm{CO})$ bands at 2026 and 1959 $\mathrm{cm}^{-1} .^{3}$ The UV/VIS spectrum shows no bands in the region $\lambda>400 \mathrm{~nm}$. When the experiment is repeated with an argon matrix containing $1.2 \% \mathrm{SO}_{2}$ a prominent band is observed in the UV/VIS spectrum at $418 \mathrm{~nm}$ [Fig. 1(a)] and the IR spectrum shows two new $v(\mathrm{CO})$ bands to higher wavenumber of each of the bands of uncomplexed $\left[\operatorname{Ir}\left(\eta^{5}-\mathrm{C}_{5} \mathrm{Me}_{5}\right)(\mathrm{CO})_{2}\right]$ [marked $\mathrm{C}$ in Fig. 2(a)]. The new bands have complex shapes with several shoulders. No 'free' $\mathrm{CO}$ is detected in the matrix. At lower $\mathrm{SO}_{2}$ concentrations $(0.6$ and $0.3 \%)$ the absorbances of the UV/VIS band and the new IR bands [Fig. 1(a) (ii) and 2(b)] decrease relative to the unperturbed $\left[\operatorname{Ir}\left(\eta^{5}-\mathrm{C}_{5} \mathrm{Me}_{5}\right)(\mathrm{CO})_{2}\right]$, but the intensities of the four new IR bands are little changed relative to one another. The UV/VIS band shifts $5 \mathrm{~nm}$ to $413 \mathrm{~nm}$ in the matrix doped with $0.6 \% \mathrm{SO}_{2}$. Spectra have also been recorded in $\mathrm{SO}_{2}-\mathrm{Ar}$ matrices for $\left[\mathrm{Rh}\left(\eta^{5}-\mathrm{C}_{5} \mathrm{Me}_{5}\right)(\mathrm{CO})_{2}\right]$, $\left[\mathrm{M}\left(\eta^{5}-\mathrm{C}_{5} \mathrm{R}_{5}\right)(\mathrm{CO})_{2}\right],\left(\mathrm{M}=\mathrm{Rh}\right.$ or $\mathrm{Ir} ; \mathrm{R}_{5}=\mathrm{H}_{5}$ or $\left.\mathrm{H}_{4} \mathrm{CF}_{3}\right), \uparrow$

$+\left[\mathrm{Rh}\left(\eta^{5}-\mathrm{C}_{5} \mathrm{H}_{4} \mathrm{CF}_{3}\right)(\mathrm{CO})_{2}\right]$ was synthesised by treatment of $\left[\mathrm{Tl}\left(\eta^{5}\right.\right.$ $\left.\left.\mathrm{C}_{5} \mathrm{H}_{4} \mathrm{CF}_{3}\right)\right]^{4}$ with $\left[\left\{\mathrm{Rh}(\mathrm{CO})_{2} \mathrm{Cl}\right\}_{2}\right]$ in $\mathrm{Et}_{2} \mathrm{O}$. The iridium analogue was made by treating an $\mathrm{Et}_{2} \mathrm{O}$ solution of $\left[\left\{\operatorname{IrL}_{2}(\mathrm{CO}) \mathrm{Cl}\right\}_{2}\right](\mathrm{L}=$ cyclooctene) with $\mathrm{CO}$ followed by $\left[\mathrm{Tl}\left(\eta^{5}-\mathrm{C}_{5} \mathrm{H}_{4} \mathrm{CF}_{3}\right)\right] \cdot{ }^{13} \mathrm{C}-\left\{{ }^{1} \mathrm{H}\right\}$ NMR data for $\left[\mathrm{M}\left(\eta^{5}-\mathrm{C}_{5} \mathrm{H}_{4} \mathrm{CF}_{3}\right)(\mathrm{CO})_{2}\right]$ in $\mathrm{CDCl}_{3}: \mathrm{M}=\mathrm{Rh}, \delta 189.4[\mathrm{~d}$, $J(\mathrm{RhC}) 85, \mathrm{CO}], 123.3\left[\mathrm{q}, J(\mathrm{FC}) 268, \mathrm{CF}_{3}\right], 100.6[\mathrm{dq}, J(\mathrm{FC}) 39$, $\left.J(\mathrm{RhC}) 5, C C F_{3}\right], 89.7[\mathrm{~d}, J(\mathrm{RhC}) 4, \mathrm{CH}], 86.9(\mathrm{~m}, \mathrm{CH}) ; \mathrm{M}=\mathrm{Ir}, \delta$ $170.3(\mathrm{~s}, \mathrm{CO}), 122.8\left[\mathrm{q}, J(\mathrm{FC}) 269, \mathrm{CF}_{3}\right], 96.2\left[\mathrm{q}, J(\mathrm{FC}) 40, C \mathrm{CF}_{3}\right]$, $85.6(\mathrm{~s}, \mathrm{CH}), 83.8[\mathrm{q}, J(\mathrm{FC}) 2 \mathrm{~Hz}, \mathrm{CH}]$.

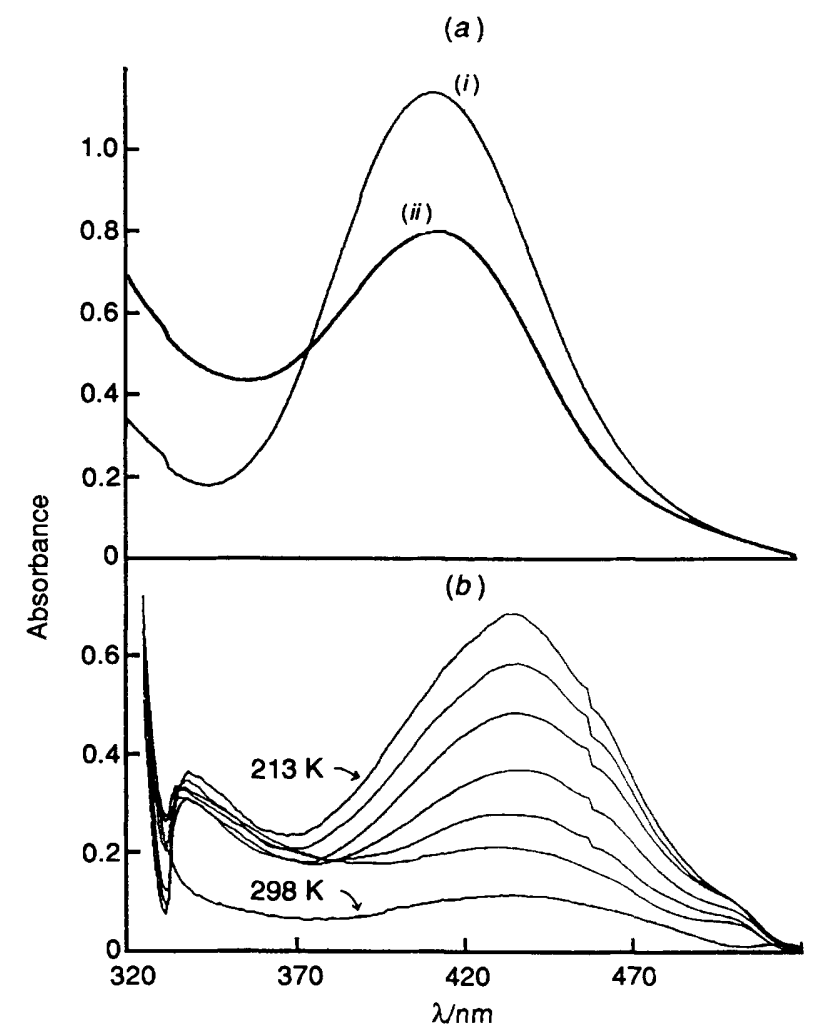

Fig. 1 The UV/VIS spectra for $\left[\operatorname{Ir}\left(\eta^{5}-\mathrm{C}_{5} \mathrm{Me}_{5}\right)(\mathrm{CO})_{2}\right](a)$ deposited in a cryogenic matrix $(20 \mathrm{~K})$ of argon with $(i) 1.2$ and $(i i) 0.6 \% \mathrm{SO}_{2} ;(b)$ deposited in a low density polyethylene disc under $0.2 \mathrm{~atm} \mathrm{SO}_{2}$. The spectra show the growth of a band at $427 \mathrm{~nm}$ upon cooling the disc from $298 \mathrm{~K}$ to $213 \mathrm{~K}$. The smaller band is assigned to the 'irreversible' product

and $\left[\operatorname{Ir}\left(\eta^{5}-\mathrm{C}_{5} \mathrm{H}_{5}\right)(\mathrm{CO})\left(\mathrm{C}_{2} \mathrm{H}_{4}\right)\right]$. The IR spectra show the presence of several extra bands on addition of $\mathrm{SO}_{2}$, which invariably lie to high frequency of those of the precursor in pure argon (Table 1).* The UV/VIS maxima vary with ligand

* The region from 1100 to $1400 \mathrm{~cm}^{-1}$ in the IR spectrum is dominated by the bands of $\mathrm{SO}_{2}$; no product bands can be distinguished. 
Table 1 Spectroscopic data for $\mathrm{SO}_{2}$ charge-transfer complexes

Matrix*

$\left[\operatorname{Ir}\left(\eta^{5}-\mathrm{C}_{5} \mathrm{Me}_{5}\right)(\mathrm{CO})_{2}\right]$

$\left[\operatorname{Ir}\left(\eta^{5}-\mathrm{C}_{5} \mathrm{H}_{5}\right)(\mathrm{CO})_{2}\right]$

$\left[\operatorname{Ir}\left(\eta^{5}-\mathrm{C}_{5} \mathrm{H}_{4} \mathrm{CF}_{3}\right)(\mathrm{CO})_{2}\right]$

$\left[\mathrm{Rh}\left(\eta^{5}-\mathrm{C}_{5} \mathrm{Me}_{5}\right)(\mathrm{CO})_{2}\right]$

$\left[\mathrm{Rh}\left(\eta^{5}-\mathrm{C}_{5} \mathrm{H}_{5}\right)(\mathrm{CO})_{2}\right]$

$\left[\mathrm{Rh}\left(\eta^{5}-\mathrm{C}_{5} \mathrm{H}_{4} \mathrm{CF}_{3}\right)(\mathrm{CO})_{2}\right]$

$\left[\operatorname{Ir}\left(\eta^{5}-\mathrm{C}_{5} \mathrm{H}_{5}\right)(\mathrm{CO})\left(\mathrm{C}_{2} \mathrm{H}_{4}\right)\right]$

PE disc

$\left[\operatorname{Ir}\left(\eta^{5}-\mathrm{C}_{5} \mathrm{Me}_{5}\right)(\mathrm{CO})_{2}\right]$

$\left[\mathrm{Rh}\left(\eta^{5}-\mathrm{C}_{5} \mathrm{Me}_{5}\right)(\mathrm{CO})_{2}\right]$ $v_{\mathrm{sym}} / \mathrm{cm}^{-1}$

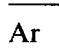

2026

2044

2058

2033

2052

2065

1987,1984

PE

2017

2025

$/ \mathrm{cm}^{-1}$

2
4
8
3
2
5
7,1984

$\mathrm{Ar}-\mathrm{SO}_{2}$

2034

2050,2048

2061(sh), 2058

2042, 2039

2058, 2056

2069(sh), 2065

2004, 1992

* Data for Ar matrices containing $1.2 \% \mathrm{SO}_{2}$.

\begin{tabular}{lll}
$v_{\text {antisym }} / \mathrm{cm}^{-1}$ & & $\lambda_{\text {max }} / \mathrm{nm}$ \\
\cline { 1 - 2 } & $\mathrm{Ar}-\mathrm{SO}_{2}$ & $\mathrm{Ar}-\mathrm{SO}_{2}$ \\
1959 & 1981,1966 & 418 \\
1977 & 1991,1982 & 405 \\
1992 & 2003,1992 & 382 \\
1970 & 1995,1979 & 433 \\
1988 & $2010,2001,1994$ & 421 \\
2004 & 2014,2004 & 384 \\
& & 404
\end{tabular}

$\mathrm{PE}-\mathrm{SO}_{2}$

2032, 2022

2043,2033
PE

1949

1960
$\mathrm{PE}-\mathrm{SO}_{2}$

1979,1966

1992,1980
$\mathrm{PE}-\mathrm{SO}_{2}$

427

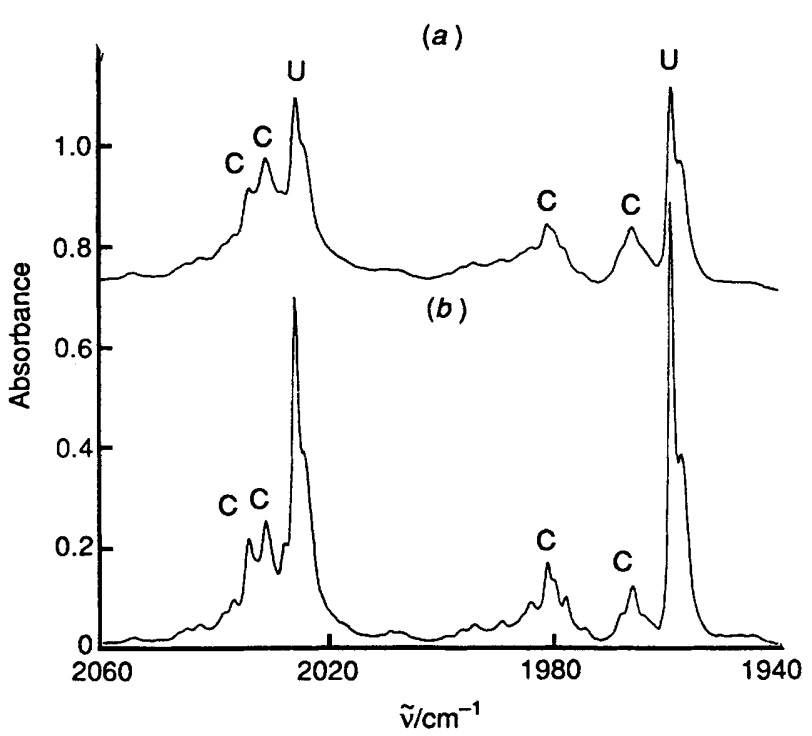

Fig. 2 The IR spectra in the CO-stretching region for $\left[\operatorname{Ir}\left(\eta^{5}\right.\right.$ $\left.\left.\mathrm{C}_{5} \mathrm{Me}_{5}\right)(\mathrm{CO})_{2}\right]$ deposited in a cryogenic matrix $(20 \mathrm{~K})$ of argon with $(a)$ 1.2 and $(b) 0.6 \% \mathrm{SO}_{2} . \mathrm{U}=$ Uncomplexed precursor, $\mathrm{C}=$ complex

and metal: $\lambda_{\max }\left(\eta^{5}-\mathrm{C}_{5} \mathrm{Me}_{5}\right)>\left(\eta^{5}-\mathrm{C}_{5} \mathrm{H}_{5}\right)>\left(\eta^{5}-\mathrm{C}_{5} \mathrm{H}_{4} \mathrm{CF}_{3}\right)$, $\mathrm{Rh}>\mathrm{Ir}$.

Similar experiments with $\left[\mathrm{M}\left(\eta^{5}-\mathrm{C}_{5} \mathrm{H}_{5}\right)\left(\mathrm{C}_{2} \mathrm{H}_{4}\right)_{2}\right](\mathrm{M}=\mathrm{Co}$, $\mathrm{Rh}$ or $\mathrm{Ir}$ ) in $2 \% \mathrm{SO}_{2}-\mathrm{Ar}$ matrices again reveal prominent $\mathrm{UV} / \mathrm{VIS}$ absorptions (Co 444, Rh 442, Ir $420 \mathrm{~nm}$ ). In the case of rhodium, the band is in a different position from that of the established $\left[\mathrm{Rh}\left(\eta^{5}-\mathrm{C}_{5} \mathrm{H}_{5}\right)\left(\mathrm{C}_{2} \mathrm{H}_{4}\right)\left(\mathrm{SO}_{2}-S\right)\right]$ complex, showing that we are not observing substitution reactions. The value of $\lambda_{\max }$ is more sensitive to the $\mathrm{SO}_{2}$ concentration than to that of the carbonyl complex.

In low density polyethylene (PE) discs the $\mathrm{SO}_{2}$ concentration and the sample temperature can be varied smoothly over a wide range. A solution of the organometallic in heptane or supercritical $\mathrm{CO}_{2}$ is applied to a PE disc, and the solvent removed in vacuo. ${ }^{5}$ The disc is mounted in a sealed cell which can be filled with a controlled pressure of $\mathrm{SO}_{2}$. When $\left[\operatorname{Ir}\left(\eta^{5}\right.\right.$ $\left.\left.\mathrm{C}_{5} \mathrm{Me}_{5}\right)(\mathrm{CO})_{2}\right]$ is treated with $0.3 \mathrm{~atm}\left(1 \mathrm{~atm} \approx 10^{5} \mathrm{~Pa}\right) \mathrm{SO}_{2}$ at $296 \mathrm{~K}$, weak bands [marked C in Fig. 3(a)] appear at 2022 and $1966 \mathrm{~cm}^{-1}, 5$ and $17 \mathrm{~cm}^{-1}$ to high frequency of the precursor absorptions respectively. On cooling in steps of $c a$. $10 \mathrm{~K}$, these bands increase in intensity progressively [Fig. 3(a)] and shoulders become apparent to high frequency. A similar experiment with UV/VIS detection shows a band at $427 \mathrm{~nm}$ which increases in intensity either on cooling [Fig. 1(b)], or on increasing the $\mathrm{SO}_{2}$ pressure. When 0.34 atm $\mathrm{SO}_{2}$ is applied at $268 \mathrm{~K}$ and then pumped away, these IR and UV/VIS bands

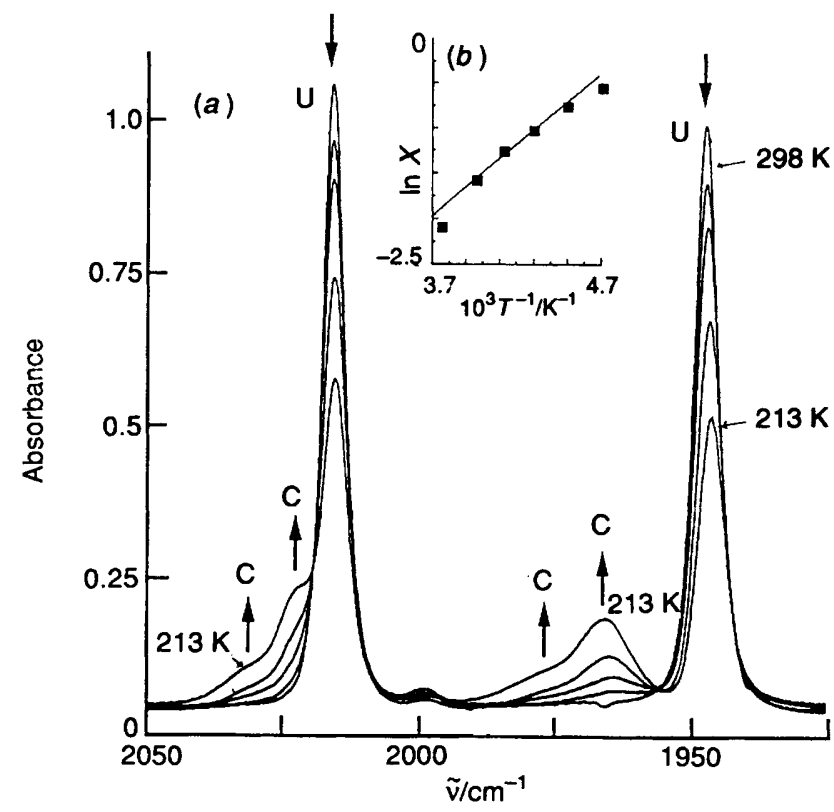

Fig. 3 (a) IR spectra for $\left[\operatorname{Ir}\left(\eta^{5}-\mathrm{C}_{5} \mathrm{Me}_{5}\right)(\mathrm{CO})_{2}\right]$ deposited in a low density polyethylene disc. The spectra show the growth of bands of complex (C) upon cooling the disc from 298 to $213 \mathrm{~K}$. U = Uncomplexed precursor. (b) Van't Hoff plot for the ratio of the integrated absorbances of the bands of $\left[\operatorname{Ir}\left(\eta^{5}-\mathrm{C}_{5} \mathrm{Me}_{5}\right)(\mathrm{CO})_{2} \cdot \mathrm{SO}_{2}\right]$ and $\left[\operatorname{Ir}\left(\eta^{5}-\mathrm{C}_{5} \mathrm{Me}_{5}\right)(\mathrm{CO})_{2}\right]: \ln X$ against $T^{-1}\left(X=A_{1949} / A_{1966}, \Delta H^{0}=\right.$ $\left.-13 \pm 3 \mathrm{~kJ} \mathrm{~mol}^{-1}\right)$

disappear completely. The process could also be reversed by warming. At higher pressures further bands are formed irreversibly. Comparable IR spectra are obtained on treating a PE disc containing $\left[\mathrm{Rh}\left(\eta^{5}-\mathrm{C}_{5} \mathrm{Me}_{5}\right)(\mathrm{CO})_{2}\right]$ with $\mathrm{SO}_{2}$ (Table 1). The effects of $\mathrm{SO}_{2}$ on the spectra of $\left[\operatorname{Ir}\left(\eta^{5}-\mathrm{C}_{5} \mathrm{Me}_{5}\right)(\mathrm{CO})_{2}\right]$ in PE discs are strikingly similar to the matrix spectra (Table 1). In the PE discs we can be certain that the two components of each IR band arise from independent metal dicarbonyl species since matrix splittings are absent from disc spectra.

The conspicuous UV/VIS bands observed in these experiments point to the formation of charge-transfer complexes of the type $\left[\mathrm{M}\left(\eta^{5}-\mathrm{C}_{5} \mathrm{R}_{5}\right) \mathrm{L}_{2} \cdot n \mathrm{SO}_{2}\right]$. Their positions are very sensitive to the electronic properties of the cyclopentadienyl ring. The bands shift to lower energy on methylating the ring for a given metal as do the ionisation energies of the complexes. ${ }^{6,7}$ Conversely they move to higher energy for each metal complex when one hydrogen on the ring is substituted by $\mathrm{CF}_{3}$. There is also a blue shift on replacing $\mathrm{Rh}$ by $\mathrm{Ir}$ which matches the increase in ionisation energy of $\left[\operatorname{Ir}\left(\eta^{5}-\mathrm{C}_{5} \mathrm{H}_{5}\right)(\mathrm{CO})_{2}\right]$ relative to 
$\left[\mathrm{Rh}\left(\eta^{5}-\mathrm{C}_{5} \mathrm{Me}_{5}\right)(\mathrm{CO})_{2}\right]{ }^{6}$ The high frequency shifts of the $v(\mathrm{CO})$ bands of the carbonyl complexes demonstrate that charge has been transferred from the metal complexes to $\mathrm{SO}_{2}$. Thus both IR and UV/VIS spectra demonstrate that the metal complex acts as a Lewis base and $\mathrm{SO}_{2}$ as the acid in the ground state of these complexes.

The enthalpy of complexation may be determined from the temperature dependence of the spectra in PE discs if we assume that the $\mathrm{SO}_{2}$ is present in constant excess. By measuring the integrated absorbance $(A)$ of the bands of $\left[\operatorname{Ir}\left(\eta^{5}-\mathrm{C}_{5} \mathrm{Me}_{5}\right)(\mathrm{CO})_{2}\right]$ at $1949 \mathrm{~cm}^{-1}$ and its $\mathrm{SO}_{2}$ complex at $1966 \mathrm{~cm}^{-1}$ and plotting $\ln \left(A_{1966} / A_{1949}\right) v s . \mathrm{T}^{-1}$ we find that $\Delta H^{0}=-13 \pm 3 \mathrm{~kJ} \mathrm{~mol}^{-1}$ [Fig. $3(b)]$.*

The IR spectra of the carbonyl complexes may be compared to those of the inner-sphere adducts with Lewis acids such as $\mathrm{HgCl}_{2}$ and with the recently described $\mathrm{H}$-bonded complexes with fluoroalcohols. ${ }^{8,9}$ However, the charge-transfer complexes with $\mathrm{SO}_{2}$ may alternatively involve outer-sphere interactions as have been described for numerous other organometallic bases interacting with organic acids. ${ }^{10}$ Sulfur dioxide has long been known to act as an acceptor towards main group bases, ${ }^{11}$ but the closest analogues may be the c.t. complexes formed between $\mathrm{SO}_{2}$ and iodide or thiolate ligands on transition metals. ${ }^{12}$ The sensitivity of the UV/VIS spectra of some of the complexes to $\mathrm{SO}_{2}$ concentration suggests that $\mathrm{SO}_{2}$ aggregates may also play a role as postulated by Kubas. ${ }^{2}$ The discovery of c.t. complexes between $\mathrm{SO}_{2}$ and simple organometallics opens opportunities for many new c.t. complexes $\dagger$ and for atom- or electron-transfer

* Measurements of $\Delta H^{0}$ for the interaction of fluoroalcohols with $\left[\operatorname{Ir}\left(\eta^{5}-\mathrm{C}_{5} \mathrm{Me}_{5}\right)(\mathrm{CO})_{2}\right]$ proved very similar whether measured in heptane solution or PE discs. ${ }^{5}$ This comparison gives confidence that the measurements reported here refiect chemical interaction with $\mathrm{SO}_{2}$, rather than a polymer property.

† Simple metallocenes and metallocarboranes also form charge-transfer complexes with $\mathrm{SO}_{2} \cdot{ }^{13}$ reactions, as well as lending support to Cramer's ${ }^{2}$ original mechanism.

\section{Acknowledgements}

We acknowledge helpful discussions with Professor D. M. P. Mingos. We are grateful to The Royal Society, The European Commission, British Gas and EPSRC for support.

\section{References}

1 G. J. Kubas, Acc. Chem. Res., 1994, 27, 183 and refs. therein

2 R. Cramer, J. Am. Chem. Soc., 1967,89,5377; R. R. Ryan, P. G. Eller and G. J. Kubas, Inorg. Chem., 1976, 15, 797.

3 A. J. Rest, I. Whitwell, W. A. G. Graham, J. K. Hoyano and A. D. McMaster, J. Chem. Soc., Chem. Commun., 1984, 624

4 P. G. Gassman and C. H. Winter, J. Am. Chem. Soc., 1986, 108, 4228.

5 A. I. Cooper, S. G. Kazarian and M. Poliakoff, Chem. Phys. Lett., $1993,206,175$.

6 N. D. Dudeney, O. N. Kirchner, J. C. Green and P. M. Maitlis, J. Chem. Soc., Dalton Trans., 1984, 1877.

7 D. L. Lichtenberger, D. C. Calabro and G. E. Kellog, Organometallics, 1984, 3, 1623.

8 F. W. B. Einstein, X. Yan, X. Zhang and D. Sutton, J. Organomet. Chem., 1992, 439, 221

9 S. G. Kazarian, P. A. Hamley and M. Poliakoff, J. Am. Chem. Soc., $1993,115,9069$.

10 T. A. Bockman and O. K. Kochi, in Photosensitisation and Photocatalysis using Inorganic and Organometallic Compounds, eds. K. Kalyanasundaram and M. Grätzel, Kluwer, Dordrecht, 1993.

11 M. M. Wong and K. B. Wiberg, J. Am. Chem. Soc., 1992, 114, 7527 and refs. therein.

12 M. R. Snow and J. A. Ibers, Inorg. Chem., 1973, 12, 224; P. G. Eller and G. J. Kubas J. Am. Chem. Soc., 1977, 99, 4346.

13 D. M. P. Mingos, N. G. Howells and Y. K. Yan, unpublished work.

Received 5th October 1994; Communication 4/06090C 